\title{
Living in Communion within Anglicanism ${ }^{1}$
}

\author{
Victor Atta-Baffoe ${ }^{2}$ \\ victorattabaffoe@yahoo.com
}

\begin{abstract}
In the Anglican Communion today, stress on tendencies such as liberalism and conservatism, evangelicalism and modernism, continues to separate people in Christ from each other. Arguments over sexuality, women's ordination, gender, inclusive language, and theological differences continue to create division and antagonism in the Church. This article develops the role of embodied community (koinonia) and sacramental participation as the vital centre of shared Anglican unity. It makes use of Paul Avis's concept of 'progressive orthodoxy' as a way of articulating what is shared by the independent churches of the Anglican Communion. The radical demand of the gospel compels us to appreciate and come to terms with Anglicanism, not so much in any specific, well defined theology, nor ecclesiastical bureaucracy, but rather in our mutual participation in the one Lord, one faith, one baptism (Eph. 4.4-6).
\end{abstract}

KEYWORDS: Anglican identity, communion, koinonia, Lambeth Conference, participation, progressive orthodoxy

\section{Setting the Context}

The drama which began as the National Church in England is now a communion of Churches. The communion is organized as independent, self-governing, national or regional Churches known as Provinces. These autonomous Churches and Provinces consist of a wide variety of races, languages, cultures and political conditions. They are in communion with each other, loyal to the Holy Scriptures, a common tradition and the continuing practice of consultation and mutual support.

1. Given as the Cheney Lecture at Berkeley Divinity School, Yale University, 21 October 2014.

2. The Rt Revd Dr Atta-Baffoe is Bishop of Cape Coast, Anglican Church of Ghana. 
Charles Henry Long, editor of Who Are the Anglicans? Profiles and Maps of the Anglican Communion describes the Anglican Communion in these words: Anglicans

- Trace their origins to the form and expression of the Christian faith which developed in the Church of England and through its missionary expansion throughout the British Isles and to other lands after the Reformation and in association with other Episcopal or Anglican Churches until the present day

- Are in communion with the See of Canterbury (and with one another) freely recognizing the Archbishop of Canterbury as the principal Archbishop and the focus of unity within the Communion

- Uphold and propagate the catholic and apostolic faith and order, based on the Scriptures and interpreted in the light of Christian tradition, scholarship, and reason. This process has found expression in the prayer books and ordinals during the 16th and 17th centuries and in their modern successors. ${ }^{3}$

The Anglican Communion has outgrown its Englishness. Today the majority of Anglicans are from the so-called 'third world' countries. The Euro-American Anglicans represent a minority. It is true that English continues to be the medium of communication of the Communion at worship during international gatherings. It should also be noted that the Book of Common Prayer has been translated into many languages for worship by various Churches. Moment by moment, the Communion becomes more integrated, more incarnated, and more contextualized in a plural world.

The 1930 Lambeth Conference description of the Anglican Communion is

a fellowship, within the One Holy Catholic and Apostolic Church, of those duly constituted Dioceses, Provinces or Regional Churches in communion with the See of Canterbury, which are bound together not by a central legislative and executive authority, but by mutual loyalty sustained through the common counsel of the Bishops in conference. ${ }^{4}$

What happened is a new sense of identity of the Communion. Here we begin to see anew the universal and particular nature of the Church. The recognition of 'union and distinction', modelled after the incarnation theology, is emphasized within the Communion.

3. Charles Henry Long (ed.), Who Are the Anglicans: Profiles and Maps of the Anglican Communion (Cincinnati: Forward Movement, 1988), p. 3.

4. Lambeth Conference 1930, Resolution 49; see http://www. anglicancommunion.org/resources/document-library/lambeth-conference/1930/ resolution-49-the-anglican-communion?author=Lambeth+Conference\&year=1930 (accessed 16 November 2015). 
We also begin to see a new sense of mission and mission theology - a shift from missions to mission. Mission is no longer considered as 'sending' and 'receiving'. Mission is no longer a matter of the 'older' Churches being responsible for the 'younger' Churches. Every Church within the Communion is both on the receiving side as well as the giving side of the partnership. Every Church is a mission to the others. Mission now becomes the duty of all Churches in the Communion, and not necessarily missionary agencies.

The Toronto Congress in 1963 emphasized this concept by calling for renewal in mutual loyalty and interdependence of the Anglican Communion. The Congress promoted growing participation and common responsibility of its members in the life and service of Christ in the Church. This concept is not to abandon our particularity or peculiarities but our separateness. It is an invitation to celebrate our unity in our diversity. Where is such unity born? The unity of the Church consists not in terms of like-minded people, or special interest groups, coming together to worship. Rather, it resides in the baptismal faith - the fact of one faith, one Lord, one baptism. This is for Anglicans the key to Ecclesiology.

The foregoing discussion tells a significant story. The spirit of Anglicanism is not to create a denomination, but, through participation and interdependence, to form the people of God. It is not a question of individual agenda or preference; neither is it a question of age, race, colour, class or gender that qualifies one to be a full member of the Communion or assume responsibility in the Church. Instead, it is God's own free gift of love and grace through baptism. It is the response to God's call to stay in a community of love which respects the integrity of the other partner. At the heart of Anglicanism is the incarnation which also explains the principle of particularity and universality. This principle continues to govern the Communion's identity and shapes its integrity.

It is reasonable to state that Anglicanism, which began as a national Church, has now developed into a global fellowship of Churches. The meeting of the bishops at the First Lambeth Conference in 1867 raised two theological issues for Anglican ecclesiology. First, a new awareness of the independence of the national Churches, and second, recognition of the fact, the necessity of finding ways for the advancement of mutual support and interdependence. ${ }^{5}$

5. See Philip Thomas, 'Doctrine of the Church', in Stephen Sykes and John Booty (eds.), The Study of Anglicanism (London: SPCK/Fortress Press, 1988), pp. 249-61. See also in the same volume, Perry Butler, 'From the Early Eighteenth Century to the Present Day', pp. 30-52. G.R. Evans and J. Robert Wright, The Anglican Tradition: A Handbook of Sources (London: SPCK/Fortress Press, 1991), p. 329. 


\section{The Mark of Anglicanism}

From the very beginning of this process (the first Lambeth Conference) any suggestion of a legislative power to centralize the Church's organizational structure was renounced. The ecclesiastical organization of the Anglican Communion is not a centralized government. What then does it mean to be Anglican? What constitutes Anglicanism, and what model can we use to identify it?

It is commonly assumed that the basis of Anglican Ecclesiology is the Thirty-nine Articles of Religion. Yet no one can deny the fact that this confessional role had already waned in Anglican consciousness as a result of the nineteenth-century socio-political and religious controversies in England. The 1968 Lambeth Conference recommended that Churches should formally distance themselves from the Articles, honouring them for their historical significance but discarding any attempt to use them as a contemporary confession of faith. ${ }^{6}$

Again, it is a common practice to determine what Anglicanism is by referring to the Book of Common Prayer. This position is also under serious pressure on several fronts today. To some extent, the Book of Common Prayer serves as the normative authority in the Anglican Communion and provides a foundation for the faith interpreted or the voice of the Church and the guide of its action. But the fact is that the Prayer Book was an outward form of an ecclesial culture and the theological definition of a view of social order, which is different from the Communion today.

Furthermore, religious pluralism and cultural diversity renders the notion of a common liturgical form of worship impractical. As part of her history, the expansion of the Church of England into various territories apparently carried with it an attitude of Western imperialism and colonialism. However, it could be said that these were accidents in history. The Anglican Communion has always resisted the temptation of pursuing a centralized and uniformed polity. The idea that characterizes the spirit of Anglicanism in its life and practice is what Paul Avis describes as 'progressive orthodoxy'. ${ }^{7}$ The idea embraces the tension between old and

6. Lambeth Conference 1968, Resolution 43; The Lambeth Conference 1968: Resolutions and Reports (London: SPCK, 1968), pp. 40-41. I am aware that some provinces in the Communion, including my own, West Africa, have retained the Articles. But still, we cannot think of the Thirty-nine Articles of Religion as the necessary instrument that holds the Anglican Communion together.

7. See Paul Avis, Anglicanism and the Christian Church (Edinburgh: T\&T Clark, 1989). I need to emphasize that the concept is fundamental to Anglican ecclesiology, and it is also evident in the works of most Anglican theologians. Particularly, this concept corresponds to Richard Hooker's ecclesiology. 
new, universality and particularity of the Christian Gospel. 'Progressive orthodoxy' is rooted in the faith inherited from the early Church, yet open to new concepts and insights in the light of contemporary understanding of the reality within which the faith is preached and lived out in the diverse cultural contexts of a pluralistic society.

\section{Communion in Spirit}

Much has been said and written on the concept of koinonia as a central focus of communion, partnership, fellowship and other values that give support to mutuality and cooperation in Anglicanism. ${ }^{8}$ The concept of koinonia is pivotal for expressing the ethos that should exist among Church members. Suffice it to say that the working out of the practical, theological and liturgical implications of this theme has undergirded much of the ecclesial and ecumenical advances. As far as the New Testament is concerned, it is a major task of the Christian Church. Allied to the theology of koinonia are such concepts as oikonomia (stewardship), oikodome (building up, edification), and katallage (reconciliation). These concepts are definitive characteristics of the Church in action. They are not necessarily ranked in any order of importance, nor are they understood to be classified as 'essentials' or 'non-essentials'.

Thus, even if it would be possible to place greater emphasis on koinonia as the foundation of our life together in the Church, it must be said that it is the people - the Church, the body of Christ - that live out faithfully, the meaning of this foundation in terms of sacrificial stewardship, unambiguous edification, and compassionate reconciliation. For all practical reasons, this must truly bring meaning to the embodiment of koinonia itself.

The creation of Adam in the Bible (Gen. 1-2), is not just the story of some individual but it is about humanity. Thus creation and humanity go

8. Koinonia (communion) literally means 'holding a common life together'. All humanity shares in common the potential to respond to the life of God. The Church holds in common that this life is revealed and offered to the world by Jesus Christ. Within Anglicanism this experience of a common life has traditionally been expressed in our use of Scripture, the Apostles' and Nicene Creeds, Baptism and the Eucharist, and the historic Episcopate, and in the formularies and constitutions of the different provinces which spell out the doctrinal and structural features of Anglicanism. See The Official Report of the Lambeth Conference 1998: July 18-August 9, 1998, Lambeth Palace, Canterbury, England (Harrisburg, PA: Morehouse, 1999), pp. 190-91; and The Virginia Report: Report of the Inter-Anglican Theological and Doctrinal Commission (London: Anglican Consultative Council, 1997), Chapter 2. 
together. And humanity is about koinonia. The creation story continues with the story of the fall (Gen. 3). The original community got disoriented and disturbed through sin. The idea of sin as it is described in the story implies that it is idolatry in the sense of replacing God with wealth, power, etc. but I dare stress that sin is also a refusal to be brotherly or sisterly, as the story of Cain and Abel demonstrates. The story of Cain and Abel is the paradigm into which the denials of human dignity whether by poverty, unjust economic order, discrimination or injustice fit.

Koinonia is created neither by numbers nor by proximity; it is created by the sense that one needs the other person to define oneself and the meaning of one's existence, and that our lives do influence each other for good or for ill. As Professor Mibti once said, 'I am, because we are; and since we are, therefore I am.' By means of this sense our acts and deeds enrich or impoverish others, and vice versa. In the New Testament, the new humanity through Christ is described in the context of a community that has been forgiven, have their burden of guilt removed and, therefore, have a new sense of their worth as human beings. This biblical insight of communion corresponds with the Ghanaian sense of communion, though not identical. For the traditional Ghanaian sense of communion and community is very much kin-group based. To that extent, it may be argued that it is a rather narrow sense of community. What Christianity has to offer is a community that goes beyond the kin-group to include all peoples (sex, race, age, colour etc.). Koinonia - communion - in this sense, as it is expressed in baptism and Eucharist, is a sharing of life, spiritual and material resources for the benefit of all. It is being able to communicate love and thus live in community of faith, Church.

The vision of koinonia as a divine mandate calls the Church into a life of mutual participation in each other's lives and circumstances. This divine mandate is beyond simply the call to bear one another's burdens, in obedience to the law of Christ. It is part of the task of the Church to give a full explication and explanation of this vision of koinonia as fundamental to the meaning of living in communion within Anglicanism. It is the effectual working out of this theological vision of koinonia that can in some way help the Anglican Communion as a whole to overcome at least some of the conceptual, attitudinal, intercultural and organizational challenges that have afflicted the Communion over the years. While it is impossible to undo the facts of history, nor deny the existence of residuals of some ancient and persistent heresies, we can certainly attempt to bring new meaning to bear on the central meaning and message of the Gospel which is the fundamental source of faith. Efforts over time have provided the 
Communion innumerable lessons for living together in communion, and they have helped to shape our sense of Communion and identity, not so much in terms of what we have, or who we are, but more so in terms of what we indeed can become, by God's grace. While at first glance the idea of communion might appear to be too idealistic, in practice it has shown the potential to serve as a common, practical, ethical standard, less subject to diverse philosophical and cultural interpretations.

Since there cannot be true communion in the context of inequality, let me raise at least two principles for consideration.

The first is communion of resources. Despite the various excellent means of celebrating our lives with each other across the Communion at different levels (i.e. prayers, hospitality), this is perhaps the weakest link in the life of the Communion. This is so because such transfer of resources from the rich to the poor is so powerful a force that it virtually occludes the readiness of the rich to be gracious recipients of what the poor have to offer. It is true to affirm that 'it is more blessed to give than to receive' (Acts 20.35); it is equally true that the Christian duty is to accept the generosity of fellow Christians without any spirit of superiority. The mandate of the Gospel still holds true for the Anglican Communion that a Church's life does not consist in the abundance of the resources, which that Church may happen to possess but being faithful to its vocation or mission.

The second is communion of the poor. It is a commonplace that the vast majority of the membership within the Communion is practically poor. The African context is one of poverty and pain, suffering and degradation. Part of it is self-induced, part inflicted by an unjust social-economic order. This virtually has rendered Africans powerless, regardless of the pomp and circumstance with which the Anglican conclaves are generally attended. This communion of the poor subsists at a deep and sustaining level of mutual solidarity and mystical fellowship. It waits, above all, to work sacrificially, to share in countless human ways, and to build upon a source of faith, hope and trust that does not lend itself to either theological affirmation or hierarchical approbation.

The innumerable personal encounters which Anglicans have with each other, and which reinforce their sense of common faith and authentic spirituality, more than attest to the fact that the measure of true communion within the Anglican Communion really consists of the power of the Spirit at work among those who acknowledge and demonstrate their need of each other, and not their need of each other's treasures. It exists at the level of having nothing, while yet possessing 
all things. It thrives on the mutual interdependence on each other's presence and not on the mutual acquaintance with each other's power. It flourishes at the level of sharing in each other's pain and possibility, and not at the heights of each other's prominence or popularity. Dispersed authenticity within global Anglicanism then, must come alive in the myriad ways by which we help each other to live into our common need of God, and our joint search for God in all convulsive and surprising ways by which we can discern together, discover together, and celebrate together. All authentic spiritual life is meant to foster the growth of individual and communal harmony. The practice of spirituality is not 'a wholesale' withdrawal from the world of economics, politics and business, but will require our engagement in the struggle for peace and social justice both locally and worldwide.

\section{Participation and Anglicanism}

We are aware that the Anglican Communion faces several challenges. At the heart of the dilemma is the question of theology. Whether we belong to the liberal or conservative, catholic or protestant, high Church or low Church, evangelical or modernist tradition, it still remains problematic in view of the growing complexity in understanding Anglicanism in terms of its changing cultural significance. I call this a crisis of theology not because of a lack of canonical, administrative or educational authority in Anglicanism; the crisis of theology must not be confused with theological plurality in the Anglican Communion.

My contention is that if theology would mean anything to the people, it ought to be addressed within the context of the people. Theology is not done in the abstract; rather, it has to address the context in which it is undertaken. Theology becomes meaningless if it fails to communicate God's love and grace to people in their situations. To some extent, theology today seems to be divorced from the very nature of the source - the faith of the Church. When this happens, theology ceases to serve its purpose - equipping the saints for their fuller participation in the mystery of Christ. When theology is divorced from the nature of the Church, it ceases to be pastoral. Theological enterprise thus becomes nothing but an ideology, and it divides instead of builds up the Church.

We are bound to draw a distinction between theology as the faith of the Church and theological opinion. What we identify as the distinctively Anglican approach to matters of faith lies in an attempt to locate those doctrines that are considered necessary to salvation, and those matters that could be left in the realm of theological opinion. On matters of theology, one will resonate with Richard Hooker that if there were one thing 
necessary to salvation, it would be the 'power of common participation'. 9 Hooker was convinced that our sacramental participation in Christ was specifically fashioned by our faith in the incarnation. For Hooker, the incarnation was to alter human nature toward conformity with God, not in the sense of producing godlike human persons. It is an enterprise of mutuality that carries with it responsibility. The centrality of participation is the spiritual journey of conversion into Christ's mystery. That conversion of life is carried on in the Church through word and sacrament.

Participation is both 'union and distinction' in the Godhead and also in the relation of God to humanity in the incarnate Lord. Hooker writes of participation in the Godhead as follows:

The persons of the Godhead, by reason of the unitie of theire subsdtance, do as necessarelie remaine one within an other as they are of necesitie to be distinguished one from an other,... and the persons of the Trinitie are not three particular substances to whome one 'generall' nature is common, but three that subsist by one substance 'which itselfe is particular' yeat they all three have it, and theire severall waies of havinge it are that which maketh their personall distinction. ${ }^{10}$

This concept reflects the relationship between Christ and the Church (people), and the people to one another. At this level, Hooker certainly moves from the level of substance to personal relations. It is at this level of relationship that participation and incarnation become intelligible as well as useful for the Church in Communion with each other. The mutual participation in the Godhead-Trinity is the archetype of our participation in the Church. Christ in the people, people in Christ, and people to one another; this is the sacramental life of the Church which is expressed in our common life and worship.

Classical Anglicanism has always emphasized the power of common participation through Church and worship; thus it is both scriptural and sacramental. Worship has been and continues to be the arena of theology in Anglicanism. This is conveyed in the maxim lex orandi, lex credendi (the law of praying is the law of belief). The faith of the Church

9. Hooker's treatise on participation occurs in Of the Laws of Ecclesiastical Polity. Book V, Chapter 51 through 56. Participation not only becomes a key to interpreting Hooker, but is also the ground of his theological enterprise. See John Booty, 'Richard Hooker' in William J. Wolf (ed.), The Spirit of Anglicanism (Wilton: MorehouseBarlow, 1979) and A.M. Allchin, Participation in God: A Forgotten Strand in Anglican Tradition (Wilton: Morehouse-Barlow, 1988) especially pp. 1-14.

10. Richard Hooker, Of the Laws of Ecclesiastical Polity V. 56.2, cited in W. Speed Hill (gen. ed.), The Works of Richard Hooker, Folger Library Edition (Cambridge, MA: Belknap Press of Harvard University Press, 1977). 
is expressed in the religious drama of the worshipping community; Church is the basis of doing theology in Anglicanism. Suffice it to say that in our participation in the household of God, the reality of Christ's presence transcends our individual competing agendas and self-interests and brings them into a community of love and unity with God and with each other. Religion becomes communal as opposed to individualistic. In our mutual participation in sacramental worship, we are transformed from our single-mindedness into an encounter with the Lord and the people of God. Both at the baptismal font and Eucharistic table, we recognize that which unites our differences and particularities is our common relationship to God.

\section{Conclusion}

In the Anglican Communion today, stress on liberalism and conservatism, evangelicalism and modernism continues to separate people in Christ from each other. Issues over sexuality, women's ordination, gender, inclusive language, and theological differences continue to create division and antagonism in the Church. Can the Church endeavour to allow our differences and plurality not to be a weakness or destroy the Church, but rather to be a source of its strength to fuller participation in God? What is important is that as individuals dedicated to living in Communion, we realize that we are not alone, but are part of a vast spiritual community guided by the power of the Divine Spirit in our dealings with others. In love God became one of us in the person of Jesus Christ (Jn 3.16), so that we might share the fullness of God in Christ through the power of the Holy Spirit. This is God's invitation to us all. It is the duty of all to respond to God in sincerity and truth. This radical demand of the gospel compels us to appreciate and come to terms with Anglicanism not so much in any specific, well defined theology, nor ecclesiastical bureaucracy, but rather in our mutual participation in the one Lord, one faith, one baptism (Eph. 4.4-6). 